\title{
Correction to: Mechanical ventilation of patients in helicopter emergency medical service transport: an international survey
}

Peter Hilbert-Carius ${ }^{1 \dagger}{ }^{\dagger}$, Manuel F. Struck ${ }^{2 *}{ }^{*}$, Veronika Hofer ${ }^{3}$, Jochen Hinkelbein ${ }^{4}$, Leif Rognås ${ }^{5}$, Jörn Adler ${ }^{6}$, Michael D. Christian7, Thomas Wurmb ${ }^{8}$, Michael Bernhard ${ }^{9}$ and Björn Hossfeld ${ }^{10}$

\section{Correction to: Scand J Trauma Resusc Emerg Med 28, 112} (2020)

\section{https://doi.org/10.1186/s13049-020-00801-1}

Following the publication of the original article [1], the authors requested to change the corresponding author from Peter Hilbert-Carius to Manuel F. Struck.

The new corresponding author Manuel F. Struck is shown in the authorship of this Correction as well as in that of the original article.

\footnotetext{
Author details

'BG Klinikum Bergmannstrost Halle gGmbH, Department of Anesthesiology, Intensive Care, Emergency Medicine and Pain Therapy, and HEMS "Christoph 84" and "Christoph 85", DRF-Luftrettung, Halle (Saale), Germany. ${ }^{2}$ Department of Anesthesiology and Intensive Care Medicine, and HEMS "Christoph 33" and "Christoph 71" Senftenberg, University Hospital Leipzig, Leipzig, Germany. ${ }^{3}$ Department of Anesthesiology, University Hospital Regensburg, Regensburg, Germany. ${ }^{4}$ Department of Anesthesiology and Intensive Care Medicine, and HEMS "Christoph Rheinland", University Hospital Cologne, Cologne, Germany. ${ }^{5}$ Danish Air Ambulance, Aarhus, Denmark. ${ }^{6}$ Luxembourg Air Rescue A.s.b.l., Sandweiler, Luxembourg. 'London's Air Ambulance, Barth's Health NHS Trust, London, UK. ${ }^{8}$ Department of Anesthesiology, University Hospital Würzburg, Würzburg, Germany. ${ }^{9}$ Emergency Department, University Hospital Düsseldorf, Düsseldorf, Germany. ${ }^{10}$ Federal Armed Forces Hospital, UIm, Department of Anesthesiology, Intensive Care Medicine, Emergency Medicine and Pain Therapy, and HEMS "Christoph 22" UIm, Ulm, Germany.
}

Published online: 17 February 2021

\section{Reference}

1. Hilbert-Carius, et al. Mechanical ventilation of patients in helicopter emergency medical service transport: an international survey. Scand J Trauma Resusc Emerg Med. 2020;28:112. https://doi.org/10.1186/s13049-02000801-1.

*Correspondence: manuelstruck@web.de

${ }^{+}$Peter Hilbert-Carius and Manuel F. Struck contributed equally to this work. ${ }^{2}$ Department of Anesthesiology and Intensive Care Medicine, and HEMS "Christoph 33" and "Christoph 71" Senftenberg, University Hospital Leipzig, Leipzig, Germany

Full list of author information is available at the end of the article

(c) The Author(s). 2021 Open Access This article is licensed under a Creative Commons Attribution 4.0 International License, which permits use, sharing, adaptation, distribution and reproduction in any medium or format, as long as you give appropriate credit to the original author(s) and the source, provide a link to the Creative Commons licence, and indicate if changes were made. The images or other third party material in this article are included in the article's Creative Commons licence, unless indicated otherwise in a credit line to the material. If material is not included in the article's Creative Commons licence and your intended use is not permitted by statutory regulation or exceeds the permitted use, you will need to obtain permission directly from the copyright holder. To view a copy of this licence, visit http://creativecommons.org/licenses/by/4.0/ The Creative Commons Public Domain Dedication waiver (http://creativecommons.org/publicdomain/zero/1.0/) applies to the data made available in this article, unless otherwise stated in a credit line to the data. 